\title{
PERAN POLITIK PEREMPUAN PONDOK PESANTREN IHYAUL ULUM DUKUN GRESIK
}

\author{
Abdulla Hubet \\ Mediyeng Ketapang Telu Karangbinangun Lamongan | hubetabd@gmail.com
}

\begin{abstract}
One of the factors that encourages women in Ihyaul-Ulum Islamic boarding school in politics is their willingness to participate in the development process, especially in regions. They view that politics is a part of the broadcasting media of the Islamic propaganda. The women's involvement of Ihyaul-Ulum Islamic boarding school in politics is not merely passive but active. It is either for supporting the ruling party or a certain administrator to delegate one of them to become a candidate in a certain position. The more elected women of the Islamic boarding school show that the political position of women is culturally very significant. They have proved to be a board member of the country, an achievement that deserves to be appreciated. In Islam, women occupy an important position as men do. Islam came with the principle of equality among all humans. The only standard is their capability in performing their duties as a legislator and as a leader.
\end{abstract}

Keywords: Politics of women, Islamic boarding school, Gresik.

Abstrak: Faktor yang mendorong perempuan pondok pesantren Ihyaul-Ulum dalam politik antara lain adalah ingin berpartisipasi dan ikut serta dalam proses pembangunan terutama di daerah. Dalam pemahaman para perempuan pondok pesantren Ihyaul-Ulum, dunia politik merupakan bagian dari media perjuangan dalam menyiarkan dakwah Islamiyah. Pola keterlibatan perempuan pesantren IhyaulUlum dalam politik tidak sebatas peran pasif tetapi aktif; baik dalam rangka mendukung partai maupun penguasa tertentu dalam mendelegasikan salah satu pengurus pondok pesantren Ihyaul-Ulum untuk menjadi calon dalam menduduki jabatan tertentu. Terpilihnya perempuan berlatar belakang pesantren, menunjukkan bahwa secara kultural, posisi politik perempuan menunjukkan perkembangan signifikan. Perempuan pesantren ternyata mampu menjadi anggota dewan. Sebuah prestasi yang pantas diapresiasi. Dalam Islam, 
perempuan menempati kedudukan penting sebagaimana laki-laki. Islam datang membawa prinsip persamaan di antara seluruh manusia, tidak ada perbedaan gender antara laki-laki dan perempuan. Tidak ada perbedaan di antara mereka dalam hal esensi alami, asalkan kapasitasnya dalam menjalankan tugas sebagai anggota badan legislatif, perempuan harus bertanggung jawab sebagaimana menjadi seorang pemimpin.

Kata Kunci: Politik perempuan, pondok pesantren, Gresik.

\section{Pendahuluan}

Manusia adalah khalifah Tuhan di muka bumi. Tugasnya memakmurkan bumi untuk kesejahteraan manusia. Dalam wacana Islam, politik (al-siyasah) secara sederhana dirumuskan sebagai cara mengatur urusan-urusan kehidupan bersama untuk mencapai kesejahteraan di dunia dan kebahagiaan di akhirat

Islam adalah agama yang melindungi setiap hak-hak manusia tanpa membedakan laki-laki maupun perempuan, yang membedakan adalah tingkat ketakwaan manusia itu sendiri. Di antara hak-hak manusia itu adalah hak untuk memperoleh pekerjaan, sebab dalam Islam tidak ada perbedaan antara perempuan dan laki-laki untuk memperoleh pekerjaan. Islam bahkan menganjurkan manusia bekerja untuk menjadikan kesejahteraan dan ketentraman keluarga. Islam mempunyai posisi yang unik karena mengakui status ekonomi perempuan yang independen dan memberi hak untuk memiliki, menggunakan dan menikmatinya tanpa perantara atau wali. ${ }^{1}$

Selama ini, politik dan prilaku politik dipandang sebagai aktivitas maskulin. Perilaku politik yang dimaksudkan di sini mencakup kemandirian, kebebasan berpendapat, dan tindakan agresif. Ketiga karakteristik tersebut tidak pernah dianggap ideal dalam diri perempuan. Karena itu masyarakat selalu memandang perempuan yang mandiri, berani mengemukakan pendapat, dan agresif, sebagai orang yang tidak dapat diterima atau diinginkan.

' Muhammad Qutub, Islam The Misunderstood Religion, Terj. Fungky Kusnaedi Timur, Islam Agama Pembebas, (Jakarta Timur: Pustaka al-Kautsar, 1997), 212-213.

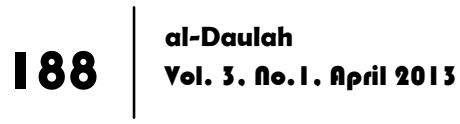


Dengan ungkapan lain perempuan dengan karakter seperti itu bukan tipe perempuan ideal.

Padahal ada tiga unsur yang merajut kepemimpinan dalam diri seseorang, yaitu kekuasaan, kompetensi diri, dan agresif kreatif. Kekuasaan, sebagai unsur penting dalam membangun dan memimpin seseorang, selalu didefinisikan sebagai kekuatan atau ketegaran atau kemampuan bertindak yang diperlukan guna mencapai sesuatu demi tujuan yang lebih besar. Pada hakekatnya, kekuasaan bersifat netral, bisa digunakan untuk kebaikan dan sekaligus untuk kejahatan. ${ }^{2}$

Kajian tentang perempuan dan gender terus menemukan momentumnya, perhatian hampir tidak pernah di berikan kepada ulama perempuan. Terdapat cukup banyak ulama perempuan dan sekaligus para perempuan yang memiliki peran penting dalam keilmuan Islam. Demikian juga terdapat perempuan-perempuan yang memiliki peran krusial dalam pembentukan lembagalembaga pendidikan Islam seperti madrasah dan lain-lain.

Meski demikian, masih banyak yang harus dilakukan untuk mengungkapkan sejarah keulamaan dan keilmuan di kalangan perempuan muslim, tidak hanya di Timur Tengah dan kawasan muslim lain, tetapi juga di Indonesia. Sebab seperti disimpulkan baik setelah mengkaji kehidupan keagamaan perempuan muslim. Posisi perempuan dalam masyarakat muslim termasuk di Indonesia tidak bisa dipahami tanpa apresiasi menyeluruh tentang konteks di mana mereka hidup, berbagai faktor budaya, politik, ekonomi, sosial dan bahkan agama saling mempengaruhi dalam menentukan posisi perempuan, tidak terkecuali ulama perempuan.

Di sini faktor religio-sosiologis menjadi sangat penting. Di lingkungan masyarakat muslim Indonesia. Seseorang baru benarbenar diakui sebagai ulama, jika telah diakui oleh komunitas nya sendiri sebagai ulama. Pengakuan itu datang bukan semata-mata

\footnotetext{
${ }^{2}$ Siti Musdah Mulia \& Anik Faridah, Perempuan dan Politik, (Bandung: Mizan, 2003), 3.
}

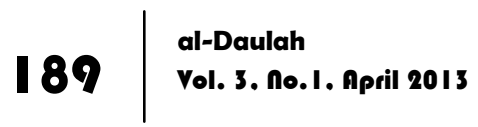


mempertimbangkan keahlian dalam ilmu agama, khususnya fiqh, tetapi juga integritas moral dan akhlak nya dilengkapi dengan kedekatan dengan umat, khususnya pada tingkat grass root (akar rumput). Kedekatan dengan umat di lapisan bawah ini bisa disimbolkan dengan kepemilikan dan pengasuhannya terhadap pesantren atau madrasah. Seperti lazimnya di lingkungan NU. ${ }^{3}$

Peranan perempuan untuk tugas-tugas seperti itu tidak dibedakan dari laki-laki. Potensi-potensi atau kemampuankemampuan untuk bertindak secara otonom diperlukan bagi tanggung jawab menunaikan amanah tersebut. Pembahasan tentang perempuan sebagai suatu kelompok memunculkan sejumlah kesulitan. Konsep "posisi perempuan" dalam masyarakat memberi kesan bahwa, ada beberapa posisi vital yang diduduki oleh perempuan di semua lapisan masyarakat. Kenyataannya bahwa, bukan semata-mata tidak ada pernyataan yang sederhana tentang "posisi perempuan" yang universal, tetapi di sebagian besar masyarakat tidaklah mungkin berkata bahwa perempuan sebagai kelompok yang memiliki kepentingan bersama. Perempuan ikut andil dalam stratifikasi sosial di masyarakat. Ada perempuan kaya, ada pula yang miskin, ada yang pandai, ada pula yang bodoh. Selain itu, latar belakang kelas kaum perempuan mungkin sama penting dengan gendernya dalam menentukan posisi mereka di masyarakat. ${ }^{4}$

Pada dasarnya perbedaan laki-laki dan perempuan dapat diwakili oleh dua konsep, yaitu jenis kelamin dan gender. Perbedaan jenis kelamin mengacu pada perbedaan fisik, terutama pada perbedaan fungsi reproduksi. Sementara itu gender merupakan konstruksi sosio-kultural. Pada prinsipnya gender merupakan interpretasi kultural atas perbedaan jenis kelamin. Bagaimanapun gender memang berkaitan dengan perbedaan jenis

\footnotetext{
${ }^{3}$ Jajat Burhanudin. Ulama Perempuan Indonesia, (Gramedia Pustaka Media, 2002), 81.

${ }^{4}$ Istibsyaroh, Hak-Hak Permpuan Relasi Jender Menurut Tafsir Al-Sya'rawi, (Jakarta: Teraju Mizan, 2004), 64.
} 
kelamin, akan tetapi tidak selalu berhubungan dengan perbedaan fisiologis seperti selama ini banyak dijumpai dalam masyarakat. ${ }^{5}$

Dalam al-Qur'an telah jelas terungkap bahwa kedudukan dan kemuliaan seseorang baik laki-laki maupun perempuan dinilai bukan dari kekuatan (superioritas) maupun kepintarannya. Tetapi lebih karena ketakwaannya, firman Allah :

"Hai manusia, sesungguhnya Kami menciptakan kamu dari seorang laki-laki dan seorang perempuan dan menjadikan kamu berbangsa bangsa dan bersuku-suku supaya kamu saling kenal-mengenal. Sesungguhnya orang yang paling mulia diantara kamu disisi Allah ialah orang yang paling taqwa diantara kamu. Sesungguhnya Allah Maha mengetahui lagi Maha Mengenal. (QS. Al- Hujurat: 13 ).6

Dari ayat tersebut maka jelaslah bahwa Islam itu menghargai harkat, martabat, derajat, hak setiap perempuan, tanpa membedakan dengan laki-laki. Perempuan bebas untuk mengembangkan ekonominya dan tidak lagi termarginalkan ${ }^{7}$

Perempuan kini berhadapan dengan perspektif modernitas yang semakin terbuka lebar. Keterbukaan ruang bagi perempuan untuk mengikuti pendidikan sampai setinggi-tingginya telah melahirkan kemampuan-kemampuan (al-ahliyah) mereka dalam segala urusan yang sebelumnya diklaim hanya menjadi milik lakilaki. Persepsi tendensius bahwa kaum perempuan kurang rasional, lebih emosional dan kurang kompenten menangani urusan domestik dan publik dibanding kaum laki-laki kini telah gugur dan tidak lagi popular. Kaum perempuan kini tengah bergerak merengkuh masa depanya dan mengubur masa lalu yang suram dan penuh nestapa. ${ }^{8}$

Diktum-diktum Islam telah memberikan ruang pilihan bagi perempuan juga laki-laki untuk menjalani peran-peran politik

\footnotetext{
${ }^{5}$ Fauzi Ridjal (ed), Dinamika Gerakan Perempuan di Indonesia, (Jakarta: Amzah, 2002), 30.

${ }^{6}$ Depag RI, Al-Qur'an dan Terjemahnya, (Surabaya: Surya Cipta Aksara, 1993), 848.

${ }^{7}$ Mansour Fakih, Analisis Gender dan Transformasi Sosial, (Yogyakarta: Pustaka Pelajar, 2007), 148.

8 Husein Muhammad.Spiritualitas Kemanusiaan Perspektif Islam Pesantren, (Jakarta: Pustaka Rihlah, 2006), 25I.
} 
domestik maupun publik, untuk menjadi cerdas dan terampil. Sejarah kenabian mencatat sejumlah besar perempuan yang ikut memainkan peran-peran ini bersama kaum laki-laki. Khadijah, Aisyah, Umm Salamah, dan para isteri Nabi yang lain, adalah perempuan-perempuan terkemuka yang cerdas. Mereka sering terlibat dalam diskusi-diskusi tentang tema-tema sosial dan politik bahkan mengkritik kebijakan-kebijakan domestik maupun publik yang patriarkis. Partisipasi perempuan juga muncul dalam sejumlah baiat (perjanjian, kontrak) untuk kesetiaan dan loyalitas kepada pemerintah. ${ }^{9}$

Sayangnya dalam perjalanan sejarah politik kaum muslimin partisipasi politik perempuan mengalami proses degradasi dan reduksi secara besar-besaran. Ruang aktivitas perempuan di batasi hanya pada wilayah domestik dan diposisikan secara subordinat. Pembatasan-pembatasan bukan hanya terbaca dalam buku-buku pelajaran, tetapi juga muncul dalam realitas sosial. Sejarah politik Islam sejak wafatnya Nabi Muhammad dan masa khulafa al rasyidun sampai awal abad XX tidak banyak menampilkan tokoh perempuan untuk peran-peran publik. ${ }^{10}$

Beberapa kalangan, lebih-lebih kaum feminis dan gerakan perempuan, menghubungkan kasus-kasus perempuan yang selalu menjadi korban dengan sistem sosial patriarkhis yang berlaku dalam masyarakat kita. Suatu sistem sosial yang berpihak pada dan dominasi kaum laki-laki. Sistem yang demikian dinilai merugikan kaum perempuan, bahkan menjadikan kaum perempuan sekedar sekrup kecil atau pelengkap dalam bangunan sosial. $^{11}$

Bagi Indonesia yang mayoritas penduduknya beragama Islam, status "setara" bagi perempuan dan peluang mereka dalam aktivitas-aktivitas politik yang sesungguhnya telah mendapat

\footnotetext{
${ }_{9}^{9}$ Husein Muhammad, Islam Agama Ramah Perempuan, (Yogyakarta: LKIS, 2004), 165.

${ }^{10}$ Ibid., 167.

" Haedar Nashir, Agama Dan Krisis Kemanusiaan Modern, (Yogyakarta: Pustaka Pelajar, 1997), 57.
} 
dasar yuridis dalam UUD 1945. Terlepas masih ada persoalan diskriminasi terhadap perempuan, sejumlah kemajuan atas status perempuan telah dicapai. Proses kemajuan bagi perempuan akan terus berlanjut, terutama pada proses demokratisasi yang ditandai dengan diselenggarakannya pemilihan umum.

Namun, dalam tataran realitas masih mengalami banyak tantangan dan hambatan, baik secara internal maupun eksternal. Sekedar contoh, adalah penetapan kuota $30 \%$ bagi perempuan sebagai calon anggota legislatif dalam undang-undang Nomor 10 Tahun 2008 tentang Pemilihan Umum. Yang menyatakan bahwa :

"Setiap partai politik peserta Pemilu dapat mengajukan calon anggota DPR RI, DPRD Provinsi dan DPRD Kabupaten / Kota untuk setiap daerah pemilihan dengan memperhatikan keterwakilan perempuan sekurang-kurangnya $30 \% " 12$

Sebagai gambaran, di DPR-RI perempuan hanya mendapatkan 11,27\% dari 550 orang, di DPD perempuan mendapat $21 \%$ dari 128 orang, dan di DPRD propinsi hanya $9 \%$ dari 1.849 orang. Padahal ketika itu, kampanye perempuan memilih perempuan diapresiasi oleh banyak kalangan dan pendidikan politik untuk masyarakat boleh dibilang lumayan besar. Fakta tersebut menunjukkan bahwa partisipasi perempuan dalam politik masih menghadapi tantangan dan hambatan. Pada kasus Pemilu 2004, dari sisi isi (content) hukum, seperti yang kita tahu, masih setengah hati dan tidak ada sanksi, begitu juga dari sisi struktur maupun kultur nya, masih sangat bias gender. Apalagi dengan ditolaknya kuota dalam undang-undang Partai Politik pada tahun 2002, membuat tidak kondusif penempatan perempuan dalam nomor urut pencalonan pada Pemilu 2004 sehingga sangat merugikan kaum perempuan.

Hal yang menarik dalam perhelatan politik akbar tersebut adalah keputusan politik yang mendapat respon positif dari partai-partai politik peserta pemilu, termasuk partai politik yang

${ }^{12}$ Undang-Undang PEMILU,(Yogyakarta: Universitas Atma Jaya, 2008), 25.

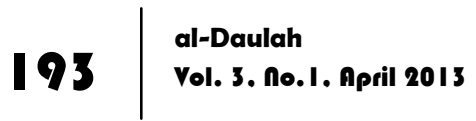


pada tahun 1999 pernah menolak presiden perempuan. Realitas ini sungguh berbeda dengan tradisi dan pikiran keagamaan yang selama ini mereka anut. Responsi dan akseptabilitas terhadap partisipasi politik perempuan tersebut diharapkan bukan hanya kepentingan politik sesaat demi menarik dukungan kaum perempuan untuk sebuah kemenangan dalam perebutan kekuasaan, tetapi karna agama memang mengabsahkan ruang politik yang luas bagi perempuan.

Gerakan kaum perempuan Indonesia membangun masa depanya untuk sebuah masa depan bangsa yang lebih adil. Kehadiran perempuan secara lebih massif dalam panggung politik struktural diharapkan akan mampu merumuskan kebijakankebijakan negara yang dapat memberdayakan berjuta-juta kaum sejenisnya, menghapus kultur diskriminatif dan menghentikan kekerasan terhadap mereka yang masih terus berlangsung secara eskalatif baik di ruang keluarga maupun sosial. Kemampuan perempuan dalam kerja-kerja politik tersebut tentu akan diuji oleh sejarah. Dan, bangsa Indonesia pasti berharap dengan optimis bahwa ketelibatan kaum perempuan dalam porsi yang lebih besar pada wilayah ini akan memberi manfaat besar bagi terciptanya keadilan dan kesejahteraan bagi semua orang

Contoh konkrit adalah dengan menyaksikan banyaknya kaum perempuan yang telah berupaya untuk menjadi pemimpin, presiden, bahkan banyak juga mereka yang ikut serta andil dalam mencalonkan anggota legislatif. Mereka meyakinkan dirinya sendiri akan mampu untuk berpikir dan berpendapat serta menjalankan suatu proses menuju bangsa yang adil, makmur yang diharapkan oleh semua masyarakat.

Dalam tulisan ini kami mengambil kajian-kajian yang berkenaan dengan popularitas gender yang terkait dengan kekuasaan dan kepemimpinan yaitu mereka calon anggota legfislatif (caleg) yang sekarang banyak didominasi oleh kaum perempuan, seperti halnya perangkat pondok pesantren yang secara kultural-emosional lebih dekat dengan NU, yang dianggap 
mumpuni dalam mengembangkan kesejahteraan masyarakat dan bisa menjadi memimpin yang lebih baik. Dalam hal ini kami akan memaparkan lebih jelas peran mereka dan berusaha mengetahui kinerja, terutama dalam wilayah politik dalam rangka memperjuangkan kepentingan kaumnya serta upaya pemberdayaan masyarakat.

Proses pemberdayaan harkat dan martabat perempuan ini, terutama dalam lingkup lokal, juga menjadi daya tarik tersendiri di Kabupaten Gresik. Meskipun panggung politik lokal banyak didominasi oleh kaum laki-laki, namun upaya kaum perempuan menunjukkan eksistensinya di ruang publik layak diapresiasi.

Secara sosiologis, Kabupaten Gresik terletak di kawasan pantura (pesisir). Sebagaimana masyarakat pesisir, konstruksi dan komposisi penduduk begitu plural, dari berbagai etnis, namun tetap didominasi oleh etnis Jawa. Secara keagamaan, Masyarakat Gresik di dominasi oleh umat Islam. Secara kultural keagamaan, tradisi Islam tradisionalis ala NU cukup dominan. Sebagaimana diketahui, kultur nahdliyyin ini ditopang oleh keberadaan pesantren yang banyak terdapat di kabupaten ini. Di antara pesantren yang cukup berpengaruh di Gresik adalah PP. Ihyaul Ulum di Kec. Dukun, mampu menjadi magnet masyarakat Gresik dalam pendidikan keagamaan dan proses pilihan politik para santri, alumni, maupun masyarakat sekitarnya.

Terpilihnya perempuan berlatar belakang pesantren, menunjukkan bahwa secara kultural, posisi politik perempuan menunjukkan perkembangan signifikan. Perempuan pesantren ternyata mampu menjadi anggota dewan. Sebuah prestasi yang pantas diapresiasi.

Dalam posisinya sebagai perempuan pesantren sekaligus anggota dewan, seorang perempuan menunjukkan pengaruhnya-baik di bidang pendidikan maupun politik. Hal ini merupakan sebuah nilai plus atas keterbukaan masyarakat Gresik dalam proses kesetaraan gender, baik di bidang politik maupun pendidikan. Bahkan jika di lihat prosentase keterwakilan kaum 
rakyat di kursi anggota dewan, terutama di Jawa Timur, menunjukkan perkembangan wacana kesetaraan gender yang mulai diterima masyarakat. Mereka juga banyak yang berlatar belakang sebagai pengasuh maupun pengajar di pesantren.

Untuk itulah, melihat realitas ini, baik dalam skala Jawa Timur maupun Kabupaten Gresik, keterlibatan kaum perempuan yang berlatar belakang pesantren menjadi sebuah fenomena menarik. Maka dalam skripsi ini, agar lebih fokus dan mendalam, penulis berusaha meneliti keterlibatan dan peranan politik perempuan pesantren dalam proses demokratisasi di wilayah Gresik. Hal ini menjadi bahan penelitian penulis, sebab baik menjelang pemilu maupun sesudahnya, peranan politik perempuan menjadi sangat signifikan, terutama jika dikaitkan dengan pemberdayaan kaumnya dan proses mengemban amanah rakyat.

Sebagai seorang yang lahir, tumbuh, dan mendapat pendidikan agama di pesantren-peranan perempuan dalam politik menjadi fokus penelitian penulis dalam skripsi ini.

\section{Gambaran Umum Pesantren Ihyaul-Ulum Dukun Gresik}

Secara sosiologis, Kabupaten Gresik terletak di kawasan pantura (pesisir). Sebagaimana masyarakat pesisir, konstruksi dan komposisi penduduk begitu plural, dari berbagai etnis, namun tetap didominasi oleh etnis Jawa. Secara keagamaan, Masyarakat Gresik di dominasi oleh umat Islam. Secara kultural keagamaan, tradisi Islam tradisionalis ala NU cukup dominan. Sebagaimana diketahui, kultur nahdliyyin ini ditopang oleh keberadaan pesantren yang banyak terdapat di kabupaten ini. Di antara pesantren yang cukup berpengaruh di Gresik adalah PP. Ihyaul Ulum di Kec. Dukun, mampu menjadi magnet masyarakat Gresik dalam pendidikan keagamaan dan proses pilihan politik para santri, alumni, maupun masyarakat sekitarnya 


\section{Pola Keterlibatan Pesantren Ihyaul-Ulum dalam Politik Praktis}

Pola keterlibatan pondok pesantren Ihyaul-Ulum dalam politik tidak sebatas peran pasif tetapi aktif; baik dalam rangka mendukung partai atau penguasa tertentu atau mendelegasikan salah satu pengurus pesantren untuk menjadi calon dalam menduduki suatu jabatan. Pondok pesantren Ihyaul-Ulum selalu mendukung partai yang berhaluan ahlus sunnah wal jama'ah. Garis ahlus sunnah wal jama'ah merupakan garis perjuangan yang paling sejalan dengan syaria'at Islam. Di dalam nilai ahlus sunnah wal jama'ah ada prinsip tawasut (sikap tengah/moderat), tawazun (seimbang), i'tidal (adil), tasamuh (toleran), dan amar ma'ruf nahu munkar (menyuruh kebaikan dan mencegah kemungkaran.

Keberadaan Nahdlatul Ulama' yang senantiasa menyatukan diri dengan perjuangan bangsa, menempatkan Nahdlatul Ulama' dan segenap warganya untuk selalu aktif mengambil bagian dalam pembangunan bangsa menuju masyarakat adil dan makmur. Karenanya setiap warga NU harus menjadi warga negara yang senantiasa menjunjung tinggi Pancasila dan UUD $1945 .{ }^{13}$ Sebagai organisasi kemasyarakatan yang menjadi bagian yang tak terpisahkan dari keseluruhan bangsa indonesia, pondok pesantren senantiasa menyatukan diri dengan perjuangan nasional bangsa Indonesia. Nahdlotul Ulama' secara sadar mengambil posisi yang aktif dalam proses perjuangan mencapai dan mempertahankan kemerdekaan, serta ikut aktif dalam penyusunan UUD 1945 dan perumusan Pancasila sebagai dasar negara

Oleh karena euforia politik semakin dinamis era reformasi pun memberikan kran demokrasi semakin terbuka lebar, sehingga banyak ornamen masyarakat yang berinisiatif mendirikan partai politik, termasuk NU di bawah komando KH. Abdurrahman Wahid (Gus Dur). Kemudian dengan kebijakan PBNU yang disepakati bersama oleh para pengurus dan umat NU, maka pada

13 Soeleiman Fadeli Mohammad Subhan, Antologi NU, Sejarah-Istilah-Amaliah-Uswah, (Jakarta: Pustaka Ma'arif NU, 2007), 68. 
tahun 1999 PBNU (KH. Abdurrahman Wahid-Gus Dur) menginisiasi lahirnya Partai Kebangkitan Bangsa (PKB).

Polarisasi perempuan pesantren terhadap politik (kekuasaan) sebenarnya-disamping berangkat dari perbedaan pemahaman mereka juga karena faktor pendekatan yang dilakukan oleh pemerintah atau partai politik terhadap mereka. Ada beberapa cara yang di lakukan partai politik untuk mempengaruhi sikap politik perempuan pesantren. Di antaranya melalui pendekatan persuasif berupa silaturrahmi, pemberian bantuan untuk keperluan pengembangan pondok pesantren, pendekatan agama lewat pengajian (penerangan agama), kegiatan tahlil, manakib, diba'an, hadrah maupun kegiatan yang bernuansa Islam lainya. Selain itu, juga di tempuh melalui organisasi, yaitu perempuan pesantren yang kebetulan berstatus sebagai pengurus organisasi dan memiliki loyalitas tinggi bagi organisasinya, maka partai politik melakukan pendekatan melalui organisasinya, misalnya, perempuan yang aktif di NU, didekati melalui pintu-pintu keorganisasian NU.

Selain itu terdapat kyai yang merespon proses politik secara samar hingga tidak jelas. Mereka memandang bahwa pemerintah adalah pihak-pihak yang memiliki kekuatan yang bisa dimanfaatkan untuk kepentingan dakwah. Menjauhi pemerintah dianggap tidak menguntungkan, sebab untuk mengembangkan ajaran Islam selalu memerlukan dukungan pemerintah; untuk apa pemerintah dijauhi. Menjauhi pemerintah akan berakibat menemui kesulitan bagi pengembangan dakwah dan pendidikan. Meski begitu, jangan terang-terangan dekat dengan pemerintah, sebab jika itu di lakukan, kyai akan di tinggal oleh umat. Pemerintah sudah terlanjur besar dan kuat, tetapi kyai merasa kasihan jika meninggalkan umat. ${ }^{14}$

${ }^{14}$ Imam Suprayogo, Kyai dan Politik: Membaca Citra politik Kyai, (Malang: UIN Malang Press, 2007), I55- 156. 


\section{Motifasi dan Orentasi Pesantren Ihyaul Ulum dalam Politik}

Faktor yang mendorong pesantren Ihyaul-Ulum dalam politik antara lain adalah ingin berpartisipasi dan ikut serta dalam proses pembangunan terutama di daerah. Sementara itu, niat khusus pesantren ihyaul-ulum ketika terlibat dalam politik adalah agar wilayah dakwah Islam lebih luas jangkauanya mudah jalannya. Hal ini sejalan dengan penegasan KH. Machfudz Ma'sum, bahwa faktor yang mendorong (motivasi) pesantren dalam berpolitik praktis adalah sebuah keinginan untuk memperlancar jalanya dakwah Islam. ${ }^{15}$

Dengan demikian, politik oleh para pengasuh pesantren ihyaul-ulum di jadikan sarana untuk memperlancar jalanya syi'ar Islam. Politik merupakan bagian dari kendaraan agama. Hal ini sejalan dengan konsep "Al-Islam huwa al-din wa al-dawlah" (Islam adalah agama dan Negara). ${ }^{16}$ Oleh karena politik (kekuasaan) merupakan bagian dari urusan agama, maka berpolitik pun merupakan aktifitas yang tidak dipersalahkan dalam agama, apalagi jika berpolitik demi kepentingan umat hal itu justru di anjurkan.

Motivasi dan orientasi politik pesantren bukan karna materi, tetapi karna ingin menjadikan politik sebagai wahana dakwah atau syi'ar Islam. Pertimbangan tersebut didasarkan juga pada sebuah pemikiran, dari pada kekuasaan di pegang sama orang yang tidak jelas motifasi dan orientasinya dalam berpolitik (kaitanya dengan kepentingan rakyat), maka lebih baik pesantren mendukung calon tertentu yang sudah bisa di pegang motivasi dan orientasinya dalam berpolitik.

Dengan demikian, terlepas dari pandangan pro-kontra terhadap aktifitas pesantren dalam dunia politik, ternyata salah satu dari pengasuh pesantren Ihyaul-Ulum Dukun Gresik tetap aktif dalam dunia politik praktis dengan motivasi dan orientasi pada perjuangan pendidikan dan dakwah Islamiyah demi rakyat.

${ }^{15}$ Qualita Ahsana, Jurnal of Indonesia Islam Community Researc, (Surabaya, 2007), 278.

${ }^{16}$ Nyai Wafiroh Ma'sum, Wawancara, Gresik, 26 Mei 2009.

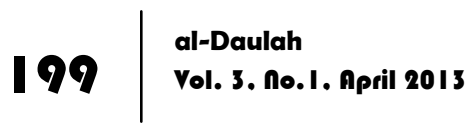


Terlepas dari melenceng dan tidaknya motivasi dan orientasi tersebut, namun pada perinsipnya pondok pesantren Ihyaul-Ulum di Gresik telah mengidealkan hal itu, dan hal itu dapat disaksikan dari fenomena dan realitas politik yang terjadi di wilayah gresik; dimana Bupatinya sekarang (kyai Robbach ma'sum) adalah figur politisi yang diantarkan oleh pesantren dan umat NU umumnya dalam menduduki jabatannya sebagai Bupati Gresik.

Keterlibatan pesantren (di bawah bimbingan kyai atau ibu nyai), merupakan upaya rasional yang dilakukan melalui pertimbangan yang matang. Keterlinatan di dunia politik bukan merupakan aktifitas yang asal-asalan. Terdapat suatu asas yang di jadikan pijakan dan pengembangan bagi pesantren Ihyaul-Ulum dalam aktifitasnya dalam dunia politik, yakni asas kemanfaatan. Selama aktifitas di aras politik itu dapat memberikan manfa'at bagi perjuangan pesantren dalam menyebarkan syi'ar Islam.

\section{Keterlibatan Perempuan Pesantren dalam Dunia Politik di Kabupaten Gresik}

Keterlibatan perempuan dalam dunia politik sebenarnya sejak dahulu. Kalau dulu perempuan dianggap belum mampu diajak bersama-sama untuk membicarakan politik. Itu dulu, tapi dalam perkembangan berikutnya, akhirnya juga bisa terlibatkan perempuan ini, hanya saja kita tidak menyalahkan sistem atau bapaknya. Perempuannya yang sering didiskriminasi di semua lini. Dengan kejadian seperti itu perempuan sering di taruh di belakang, kurang maksimal. Tapi saya yakin kemampuan perempuan sama dengan laki-laki. Dan justru ada foudnya, misalnya, perempuan punya rasa ketelatenan yang sebagian kecil dimiliki oleh seorang laki-laki. Tanggung jawab, sebenarnya lebih besar perempuan, saya gak ngerti apa karena takutnya salah melangkah sehingga kalau di beri tugas itu serius sekali. Tapi bapak-bapak kan gak? Lebih nyantai. Jadi ini sebagian kelebihan 
dari perempuan menurut saya. ${ }^{17}$ Jadi perempuan pantas untuk di libatkan dalam dunia politik.

Menurut saya mungkin juga seluruh perempuan yang lain melibatkan kaum perempuan dalam dunia perpolitikan itu di perbolehkan dan sah-sah saja bagi perempuan yang mampu dalam dunia politik, bukan hanya sekedar jabatan atau ingin dikenal di wilayahnya. Tapi kita harus bersungguh-sungguh menjalankan perintah agama, dengan adil dan bijaksana dalam menjalankan amanah yang di berikan masyarakat kepada kita. ${ }^{18}$

Kalau dicermati peran politik perempuan dari tahun ke tahun, menurut hemat saya masih sangat memprihatinkan. Secara kuantitas, caleg perempuan memang mengalami kenaikan signifikan, tetapi secara kualitas masih harus terus ditingkatkan. Politik di sini bukan hanya sekedar politik partisan an-sich, tetapi lebih pada politik kebijakan dan keberpihakan kepada perempuan. ${ }^{19}$ Perempuan masih diperankan sebagai obyek dan bukan subyek dalam kehidupan politik kita. Boleh saja sejak tahun 2004 kuota sepertiga perempuan dalam pencalonan legislatif sudah dilakukan dalam pemilu, namun hal itu tidak berjalan lurus dengan keterwakilan perempuan di legislatif yang hanya $\pm 11,8 \%$, sehingga kita masih khawatir peran politik perempuan masih sekedar formalitas dan belum masuk pada inti persoalan. ${ }^{20}$

Saya sudah lama terjun di dunia politik sejak ikut PPP pada tahun 1990an. Ketika itu saya sudah masuk di pengurusan GPK (gerakan pemuda ka'bah), kalau sekarang seperti GARDA BANGSA yang ada di PKB. Saya masuk di pengurus harian kabupaten Gresik. ${ }^{21}$

Selama ini tidak ada masalah, artinya harus pandaipandainya kita mengatur waktu. Toh di dalam pondok kita gak ngijeni

\footnotetext{
${ }^{17} \mathrm{lbid}$.

${ }^{18}$ Nyai Sakinah Ma'sum, Wawancara, Gresik, 26 Mei 2009.

${ }^{19} \mathrm{lbid}$.

20 Hanun Asrohah, Dkk, Perempuan dalam Prespektif dan Aksi, (Surabaya: IAIN Sunan Ampel, 2006), 117.

21 Nyai Wafiroh Ma'sum, Wawancara, Gresik, 26 Mei 2009.
} 
(sendirian) di sini (pon-pes ihyaul-ulum) ada Bu Nyai Sakinah dan ada yang lain seperti para ustadz dan ustadzah yang lain, jadi mungkin pada waktu kita di butuhkan kita harus bisa membagi waktu. Kita menentukan dan memberikan pengarahan misalnya, hari ini, tanggal sekian dan jam sekian, kita mengenal waktu yang kosong juga. Yang ke dua, bisa jadi tidak harus tatap muka kan!! Kita memberikan bimbingan gak harus tatap muka atau gak harus ketemu memberikan ceramah itu tidak, banyak cara-cara lain yang kita sampaikan kepada santri-santri kita di dalam pondok pesantren. Dalam bahasa kita, kita mengatakan (gak ada dalang keentekan lakon). ${ }^{22}$

\section{Afiliasi Politik Perempuan Pesantren Ihyaul-Ulum dalam Pemilu Legislatif}

Di mana beberapa perempuan pondok pesantren ihyaul-ulum di kabupaten gresik banyak sekali yang berafiliasi dengan PKB dengan alasan masing-masing. Saya berafiliasi dengan partai PKB. Mengapa? Karena saya orang NU. Kedekatan NU dengan PKB bahkan semakin tak terpisahkan, ketika Abdurrahman Wahid yang mendirikan PKB ketika ia masih menjabat Ketua Umum Tanfidziyyah NU kemudian menjadi Ketua Dewan Syura PKB. Posisi sangat penting yang bukan tidak mirip dengan posisi Presiden Soeharto sebagai "Ketua Dewan Pembina" Golkar masa lalu membuat KH. Abdurrahman Wahid sangat kuat visi warga Nahdliyyin umumnya. Dengan posisi ini Abdurrahman Wahid tidak lagi sekedar bertumpu pada kharisma pribadinya sebagai mantan Ketua Umum PBNU, tetapi juga pada kerangka organisasional PKB untuk mengendalikan dan mengarahkan aktualisasi politik warga Nahdliyyin. ${ }^{23}$

Bagi PKB kelekatan dengan NU merupakan keniscayaan jika ingin tampil secara signifikan dalam kancah politik Indonesia. Hampir bisa dipastikan, tanpa dukungan NU, warga Nahdliyyin

22 Ibid.
${ }^{23}$ Ibid. 
juga memberikan suaranya secara lebih banyak dalam Pemilu 1999 lalu kepada parpol-parpol Nahdliyyin lain, seperti Partai Nahdlatul Ummah (PNU), Partai Kebangkitan Umat (PKU), atau bahkan kepada Partai SUNI.

Dengan terseretnya NU ke dalam politik PKB, maka "political-oriented kiyai" mendapatkan momentumnya, yang pada gilirannya mengorbankan sebagian kiyai-kiyai lain yang berusaha memelihara NU pada relnya yang benar sebagai organisasi sosial keagamaan sesuai dengan Khittah 1926. Kiyai-kiyai berorientasi politik kelihatan cukup sadar tentang hubungan yang erat antara knowledge and power (pengetahuan dan kekuatan), bahwa ilmu-apalagi ilmu agama-yang memiliki aura ilahiah-dapat diaktualisasikan ke dalam politik dan kekuasaan. Reformasi dan liberalisasi politik merupakan momentum yang sangat baik bagi para kyai berorientasi politik untuk tampil kembali.

Saya berafiliasi politik ke partai kebangkitan bangsa (PKB) versi Gus Dur. Saya mendukung keberadaan PKB sejak awalnya berdirinya PKB. Saya mendukung PKB karna nilai-nilai perjuanganya sesui dengan visi dan misi saya (yang berhaluan dengan Ahlussunnah Waljama'ah). ${ }^{24}$ Sebelum PKB berdiri, saya mendukung Partai Persatuan Pembangunan (PPP), sebuah partai yang dangat getol dengan perjuangan syiar islam. Saya juga sempat bergabung dengan Partai Nahdlotul Ulama' (PNU). Setelah ada kebijakan pemerintah yang mengharuskan semua partai harus bergabung dengan salah satu partai dari tiga partai yang diakui pemerintah waktu itu, yakni PPP, GOLKAR dan PDI. Saya bergabung dengan PPP, bahkan salah satu cacak saya (KH.Makhfudz Ma'sum) menjadi ketua PPP cabang gersik. ${ }^{25}$

Kalau boleh berbangga saya ingin mengatakan, tidak ada partai yang secara khusus memberikan badan otonom tersendiri. Nah, PKB membentuk sebuah organisasi perempuan yang memiliki otonomi yang sangat luas yang bernama PPKB

\footnotetext{
${ }^{24}$ Nyai Sakinah, Wawancara, Gresik, 26 Mei 2009.

25 lbid.
} 
(pergerakan perempuan kebangkitan bangsa) yang di beri hak menentukan kepengurusan sendiri dan menjabarkan program partai yang sesuai dengan kebutuhan perempuan.

Karena adanya kesetaraan gender menyadarkan kaum perempuan akan hak dan kewajibannya dalam kehidupan politik; melakukan upaya pemberdayaan dalam berbagai aspek kehidupan untuk meningkatkan peran politik perempuan; melakukan kontrol terhadap penguasa dan pelaksana pembangunan dengan memberikan kontribusi optimal dalam menegakkan moral politik; mewujudkan keterwakilan perempuan pada posisi pengambilan keputusan dan penentuan kebijakan di partai politik, lembaga tertinggi dan tinggi negara secara proporsional; serta melaksanakan sosialisasi politik yang berperspektif perempuan untuk mencapai kesetaraan dan keadilan gender. ${ }^{26}$

Dalam lingkungan NU sendiri terdapat Maklumat akan pengakuan tentang kesetaraan gender yang dikeluarkan pada Munas NU di Lombok pada tahun 1997. Munas tersebut melahirkan suatu keputusan atau maklumat tentang "Kedudukan Perempuan Dalam Islam" (Makanah al-Mar'ah fi al-Islam). Pokokpokok pikiran yang terkandung dalam maklumat tersebut dapat disimpulkan dalam 5 (lima) poin berikut:

a. Islam mengakui eksistensi perempuan sebagai manusia yang utuh dan karenanya patut dihormati.

b. Islam mengakui hak perempuan sama dengan hak laki-laki dalam hal pengabdian kepada agama, nusa, dan bangsa.

c. Islam mengakui adanya perbedaan fungsi antara laki-laki dan perempuan yang disebabkan karena perbedaan kodrati.

d. Islam mengakui peran publik perempuan di samping peran domestiknya.

e. Ajaran Islam yang menempatkan perempuan pada posisi yang setara dengan laki-laki itu dalam realitasnya telah 
mengalami distorsi akibat pengaruh kondisi sosial dan budaya.

Menarik dicatat bahwa Munas kali ini secara intens membahas masalah demokrasi dan hak-hak asasi manusia (HAM), dua isu yang sedang menjadi tema pokok dalam setiap diskursus ilmiah, baik dalam forum nasional maupun internasional. Kedua isu itu amat terkait dengan pembicaraan soal kesetaraan gender yang menjadi isu global saat ini. Untuk menyatakan dirinya sebagai organisasi pendukung nilai-nilai demokrasi dan HAM, mau tidak mau NU harus juga menerima ide kesetaraan gender yang tentu saja dalam implementasinya pada program organisasi disesuaikan dengan tradisi dan nilai-nilai keislaman yang dianut NU. ${ }^{27}$

Maklumat itu sangat strategis dan sangat signifikan, terutama dalam memberi justifikasi upaya-upaya pemberdayaan perempuan di lingkungan NU. Sehingga organisasi-organisasi perempuan yang menjadi Badan Otonom NU, seperti Muslimat, Fatayat dan IPPNU merasa lebih mantap dalam mengelola dan mengembangkan program-program yang berkaitan dengan pemberdayaan dan peningkatan kesejahteraan perempuan.

\section{Analisis Peran Politik Perempuan Pesantren Ihyaul-Ulum Dukun Gresik Pada Pemilu Legislatif Tahun 2009}

Peran perempuan di ranah publik memiliki legitimasi yang sangat kuat di dalam Islam baik secara teologis, filosofis, normatif maupun kultural. Secara struktural, sepanjang sejarah Nahdlatul Ulama (NU) memang tidak pernah dipimpin oleh seorang perempuan, tetapi secara kultural perempuan di lingkungan pesantren memiliki peluang yang sangat besar untuk berpartisipasi di ruang publik bahkan menjadi pemimpin di tingkat nasional. 
NU mendirikan organisasi perempuan seperti Muslimat, Fatayat dan Ikatan Pelajar Putri Nahdlatul Ulama (IPPNU) saya kira salah satu di antara tujuannya adalah memberikan ruang untuk pengkaderan politik bagi perempuan. Pengertian politik di sini dalam pengertian secara luas, sebagai sarana perjuangan untuk mencapai perubahan kondisi yang lebih baik (amar ma'ruf nahi mungkar).

Keputusan tersebut tidak hanya membaggakan perempuan di lingkungan pesantren karena telah memiliki landasan yuridis yang sah, tetapi dijadikan pegangan juga oleh gerakan perempuan dan lembaga-lembaga di luar struktur NU dalam melaksanakan penyadaran terhadap kaum perempuan di Indonesia. Dalam keputusan tersebut secara tegas mensyaratkan kualitas, kapasitas, kapabilitas dan ekseptabilitas. Syarat-syarat tersebut berlaku umum bagi laki-laki maupu perempuan dan selayaknya dijadikan sebagai dasar pertimbangan dalam menetapkan pemimpinan bangsa, tanpa terjebak secara seksis.

Secara kelembagaan, fatayat NU sebagai badan otonom NU saat ini memerankan peran politiknya dengan kerja-kerja advokasi untuk pemberdayaan perempuan. Sekedar contoh, Fatayat NU berhasil mewarnai bahtsul masail pada munas NU di Surabaya tahun 2006 mengenai pencegahan trafiking. Mungkin pertama kali terjadi dalam sejarah NU, agenda dan rumusan naskah akademik yang berisi argumentasi fighiyyah dengan referensi literatur kitab kuning yang mu'tabar sebagai rujukannya disiapkan dan ditulis sepenuhnya oleh tim pucuk pimpinan fatayat NU yang seluruhnya adalah perempuan.

Di awal reformasi, Khofifah Indar Parawansah sebagai Menteri pemberdayaan perempuan saat Gus Dur atau K.H. Abdurrahman Wahid menjadi presiden RI, ia mampu mendorong lahirnya intruksi presiden no. 9 tahun 2000 tentang pengarus utamaan gender dalam pembangunan Nasional.

Selain itu secara eksplisit di sebutkan bahwa dalam konteks peran publik menuret prinsip Islam, perempuan diperbolehkan 
melakukan peran-peran tersebut dengen konsekwensi bahwa ia dapat dipandang mampu dan memiliki kapasitas untuk menduduki peran dan sosial politik tersebut. Dengan kata lain bahwa kedudukan perempuan dalam proses sistem negara-bangsa telah terbuka lebar, terutama perannya dalam masyarakat majemuk ini, dengan mengingat bahwa kualitas, kapasitas dan kapabilitas dan ekseptabilitas bagaimanapun, harus menjadi ukuran, sekaligus tanpa melupakan fungsi kodrati perempuan sebagai sebuah keniscayaan.

Dari uraian di atas dapat dianalisa bahwa pondok pesantren Ihyaul Ulum terlibat dalam dunia politik karena memang secara personal, mereka aktif di dunia politik. Dalam pemahaman para perempuan pondok pesantren Ihyaul-Ulum, dunia politik merupakan bagian dari media perjuangan dalam menyiarkan dakwah Islamiyah. Pola keterlibatan perempuan pesantren IhyaulUlum dalam politik tidak sebatas peran pasif tetapi aktif; baik dalam rangka mendukung partai maupun penguasa tertentu dalam mendelegasikan salah satu pengurus pondok pesantren Ihyaul-Ulum untuk menjadi calon dalam menduduki jabatan tertentu.

Terpilihnya perempuan berlatar belakang pesantren, menunjukkan bahwa secara kultural, posisi politik perempuan menunjukkan perkembangan signifikan. Perempuan pesantren ternyata mampu menjadi anggota dewan. Sebuah prestasi yang pantas diapresiasi.

Dalam posisinya sebagai pengasuh pesantren sekaligus anggota dewan, seorang perempuan menunjukkan pengaruhnya-baik di bidang pendidikan maupun politik. Hal ini merupakan sebuah nilai plus atas keterbukaan masyarakat Gresik dalam proses kesetaraan gender, baik di bidang politik maupun pendidikan. Bahkan jika di lihat prosentase keterwakilan kaum rakyat di kursi anggota dewan, terutama di Jawa Timur, menunjukkan perkembangan wacana kesetaraan gender yang 
mulai diterima masyarakat. Mereka juga banyak yang berlatar belakang sebagai pengasuh maupun pengajar di pesantren

Bagi PKB kelekatan dengan NU merupakan keniscayaan jika ingin tampil secara signifikan dalam kancah politik Indonesia. Hampir bisa dipastikan, tanpa dukungan NU, warga Nahdliyyin juga memberikan suaranya secara lebih banyak dalam Pemilu 1999 lalu kepada parpol-parpol Nahdliyyin lain, seperti Partai Nahdlatul Ummah (PNU), Partai Kebangkitan Umat (PKU), atau bahkan kepada Partai SUNI.

Dengan terseretnya perempuan pesantren ke dalam politik, maka "political-oriented" mendapatkan momentumnya, yang pada gilirannya mengorbankan sebagian perempuan lain yang berusaha memelihara NU pada relnya yang benar sebagai organisasi sosial keagamaan sesuai dengan Khittah 1926. Kyai-kyai berorientasi politik kelihatan cukup sadar tentang hubungan yang erat antara knowledge and power (pengetahuan dan kekuatan), bahwa ilmuapalagi ilmu agama-yang memiliki aura ilahiah-dapat diaktualisasikan ke dalam politik dan kekuasaan. Reformasi dan liberalisasi politik merupakan momentum yang sangat baik bagi para kyai berorientasi politik untuk tampil kembali.

Kemudian elemen selanjutnya yang dapat dimanfaatkan untuk menimbulkan motifasi partisipasi politik kaum nahdiyin adalah aspek ekslusivisme NU yang diwujudkan melalui tradisi pesantrenya dan basis dukungan tanpa reseve dari komunitas pluralis. Sudah menjadi rahasia umum bahwa komunitas rural dengan sekian banyak karakteristiknya, merupakan komunitas yang sangat di andalkan oleh elite NU untuk mendapatkan legitimasi patronase kehidupan sosial, ternasuk dalam kehidupan politik. Realita kultural yang menunjukan komunitas NU sebagai komunitas yang eksklusif bukan inklusif, semakin menambah prediksi bahwa kedua elemen terakhir ini dapat dimanfaatkan untuk memotivasi setiap individu dalam berpartisipasi aktif di bidang politik, minimal melalui pemberian suara pada saat pemilihan umum berlangsung. 
Tinjauan Fiqh Siyasah terhadap Peran politik perempuan dalam Proses Pemilu Legislatif

Beberapa hal yang mempengaruhi belum terwujudnya keserasian jender antara lain; masih kuatnya nilai-nilai sosial budaya yang patriarkis. Nilai-nilai ini yang menempatkan laki-laki dan perempuan pada kedudukan dan peran yang berbeda dan tidak setara. Keadaan ini ditandai dengan adanya pembakuan peran, beban ganda, subordinasi, marjinalisasi, dan diskriminasi terhadap perempuan yang menyebabkan perempuan tidak memiliki akses, kesempatan dan kontrol atas pembangunan yang adil dan setara dengan laki-laki. Di samping itu, ketidak tepatan pemahaman ajaran agama seringkali menyudutkan kedudukan dan peranan perempuan di dalam keluarga dan masyarakat. ${ }^{28}$

Islam sebagai agama samawi terakhir, diyakini sebagai agama yang universal tidak terbatas waktu dan tempat. Al-Qur'an sendiri menyatakan bahwa Islam datang sebagai rahmat bagi alam semesta. Di sisi lain, ajaran Islam diyakini sebagai risalah yang sempurna dan dapat digunakan sebagai pedoman umat manusia. Keadilan yang proporsional antara laki-laki dan perempuan perlu di ciptakan dengan menciptakan dan mempertegas penafsiranpenafsiran ayat-ayat al-Qur'an dan hadis Nabi Muhammad saw sSesuai dengan zamannya atau konteksnya. Kerangka pemikiran ini tidak menyalahi tujuan atau maksud Tuhan menurunkan syari'at kepada manusia yaitu untuk kemaslahatan umat manusia baik di dunia maupun di akhirat.

Ketika bicara politik, mau tidak mau kita harus berbicara insan politiknya. Insan politik yang dimaksud di sini adalah manusia sebagai pelaku dan sekaligus obyek politik. Pada dasarnya semua wacana pelaku politik telah menjadi kajian dan ulasan dari kiab-kitab fiqh politik, namun dalam hal ini masih ada wacana pelaku politik yang terlupakan, yaitu wacana politik kaum perempuan. Sebagai salah satu pelaku dan pencipta wacana

${ }^{28}$ Khofifah Indar Parawansah. Mengukir Paradigma Menembus Tradisi, (Jakarta: Pustaka LP3ES, 2006), 23. 
politik, kaum perempuan tidak mendapat tempat yang berarti, bahkan termaginalkan dalam kajian fiqh politik. Diakui atau tidak, domain yang disediakan oleh fiqh politik, misalnya tentang lembaga-lembaga pemerintahan, seperti Imamah, perwakilan, kementerian dan sebagainya. Tampaknya lebih akrab dengan aktivitas laki-laki dibandingkan dengan aktivitas perempuan. ${ }^{29}$

Oleh karena itu kedudukan perempuan dalam fiqh politik ini merupakan agenda tersendiri dan sangat penting untuk dilihat. Persoalannya tidak sekedar mempertanyakan kembali boleh dan tidaknya perempuan menjadi imam (pemimpin), tetapi bagaimana konsepsi fiqh dalam memandang peran politik perempuan secara umum. Secara garis besar, dalam membicarakan keberadaan hakhak kaum perempuan berpolitik ada tiga pendapat yang berkembang sebagaimana yang diterangkan di bawah ini.

Islam sejak awal telah memperkenalkan konsep keterlibatan perempuan dalam peran politik. Secara eksplisit kelompok ini mengatakan bahwa perempuan mempunyai hak pilih dalam berpolitik. Mereka juga diizinkan memangku tugas-tugas politik seberat yang dipangku oleh laki-laki. Kaum ulama dari golongan dari kelompok Khawarij dan Musyabbihah menggunakan dalildalil al-Qur'an tentang konsep 'adalah (keadilan) dan musawah (persamaan) yang selalu dijunjung tinggi dalam Islam. dan juga sebagai organisasi Islam terbesar di indonesia, Nahdlatul Ulama (NU) tidak saja selalu menghiasi wacana publik Indonesia, tetapi juga menjadi inspirasi bagi gerakan dan pemikiran keislaman yang berwawasan kebangsaan, respon terhadap perubahan dan akomodatif terhadap kebudayaan lokal nusantara. NU selalu memposisikan diri sebagai jangkar nusantara, terutama yang digalang oleh kader-kader mudanya.

Mereka mempunyai gagasan keagamaan progresif dalam merespon modernitas dengan menggunakan basis pengetahuan tradisional yang mereka miliki setelah di persentuhkan dengan

${ }^{29}$ Syafiq Hasyim, Hal-Hal yang tak Terpikirkan tentang Isu-Isu Keperempuanan dalam Islam, (Bandung: Mizan. 2002), 189. 
pengetahuan baru dari berbagai khazanah modern. Mereka tidak hanya peduli dengan modernitas yang terus di kritik dan disikapi secara hati-hati, tetapi juga melakukan revitalisasi tradisi. ${ }^{30}$

Dalam konteks ini, NU menjadikan kepercayaan teologis sebagai basis pengembangan masyarakat dengan mengusung isuisu universal seperti, HAM, demokrasi, civil society termasuk juga kesetaraan gender

Pembagian kerja antara sektor publik dengan domestik adalah pilihan masing-masing individu perempuan dan ini patut di hargai. Kaum feminis memperjuangkan hak-hak perempuan dalam kancah yang lebih luas dimana perempuan di beri kebebasan dalam memilih dan tidak ada paksaan sebagai ibu rumah tanggah saja. Ia juga memerlukan kehidupan lain di luar yang dapat dan mampu mengaktualisasikan dirinya dengan baik. Oleh karna itu, pilihan perempuan kemasalah kemasyarakatan dan kenegaraan tidak dapat di abaikan begitu saja.

Agama adalah nasehat bagi laki-laki dan perempuan secara umum dan apa yang lebih dari sekedar nasihat, berupa tugas pengawasan atas para pejabat yang pengawasan itu merupakan satu cabang dari amar ma'ruf nahi munkar juga. ${ }^{31}$

Dua tugas berupa pembuatan perundang-undangan dan pengawasan atas wewenang eksekutif, merupakan tugas "umat khusus" yang di wajibkan oleh Allah atas umat umum baik lakilaki maupun perempuan untuk membentuknya, sebagaimana firman Allah dalam QS. Ali Imran: 104.

Selain itu, secara eksplisit disebutkan bahwa dalam konteks peran publik menurut prinsip Islam, perempuan diperbolehkan melakukan peran-peran tersebut dengan konsekwensi bahwa ia dapat dipandang mampu dan memiliki kapasitas untuk menduduki peran sosial dan politik tersebut. Dengan kata lain bahwa kedudukan perempuan dalam proses sistem negara-bangsa telah terbuka lebar, terutama peranya dalam masyarakat majemuk

\footnotetext{
${ }^{30} \mathrm{http}: / /$ wmw.gp-ansor.com

${ }^{31}$ Farid Abdul Khaliq, Fikih Politik Islam, (Jakarta: Amzah, 2005), 129.
}

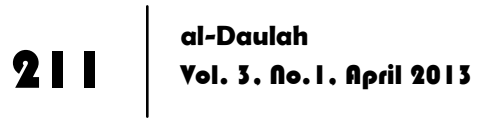


ini, dengan tetap mengingat bahwa kualitas, kapasitas, kapabilitas dan akseptabilitas bagaimanapun, harus menjadi ukuran sekaligus tanpa melupakan fungsi kodrati perempuan sebagai sebuah keniscayaan.

\section{Penutup}

Perempuan pesantren Ihyaul Ulum Gresaik telah ikut andil peran dalam pemilu legislatif tahun 2009 yaitu sebagai calon legislatif hingga mampu menghantarkan salah satu dari mereka terpilih sebagai badan anggota legislatif tahun 2009 - 2014 .

Menurut tinjauan fiqh siyasah, peran dan posisi perempuan pesantren dalam calon pemilu legislatif tahun 2009, diperbolehkan. Perempuan menempati kedudukan penting yang tidak pernah terjadi sebelumnya. Hal itu disebabkan Islam datang membawa prinsip persamaan di antara seluruh manusia, tidak ada perbedaan gender antara laki-laki dan perempuan. Sebab sebagian dari mereka berasal dari sebagian yang lain. Laki-laki dari perempuan dan perempuan dari laki-laki. Tidak ada perbedaan di antara mereka dalam hal esensi alami, asalkan kapasitasnya dalam menjalankan tugas sebagai anggota badan legislatif, perempuan harus bertanggung jawab sebagaimana menjadi seorang pemimpin.

\section{Daftar Pustaka}

Asrohah, Hanun, dkk. Perempuan dalam Prespektif dan Aksi. Surabaya: IAIN Sunan Ampel, 2006.

Burhanudin, Jajat. Ulama Perempuan Indonesia. Jakarta: Gramedia Pustaka Media, 2002.

Departemen Agama RI. Al-Qur'an dan Terjemah. Surabaya: Surya Cipta Aksara, 1993.

Fakih, Mansour. Analisis Gender dan Transformasi Sosial. Yogyakarta: Pustaka Pelajar, 2007. 
Fauzi, Ikhwan. Perempuan dan Kekuasaan, Menulusuri Hak Politik dan Kekuasaan Gender dalam Islam. Jakarta: Amzah, 2002.

Hasyim, Syafiq. Hal-Hal yang tak Terpikirkan tentang Isu-Isu Keperempuanan dalam Islam. Bandung: Mizan. 2002.

Istibsyaroh. Hak-Hak Permpuan Relasi Jender Menurut Tafsir AlSya'rawi. Jakarta: Teraju Mizan, 2004.

Khaliq, Farid Abdul. Fikih Politik Islam. Jakarta: Amzah, 2005.

Muhammad, Husein. Islam Agama Ramah Perempuan. Yogyakarta: LKIS, 2004.

Muhammad, Husein. Spiritualitas Kemanusiaan Perspektif Islam Pesantren. Jakarta: Pustaka Rihlah, 2006.

Mulia, Siti Musdah \& Anik Faridah. Perempuan dan Politik. Bandung: Mizan, 2003.

Mulia, Siti Musdah. Muslimah Perempuan Pembaru Keagamaan Reformis. Bandung: Mizan. 2002.

Parawansah, Khofifah Indar. Mengukir Paradigma Menembus Tradisi. Jakarta: Pustaka LP3ES, 2006.

Qualita Ahsana. Jurnal of Indonesia Islam Community Research, Surabaya, 2007

Qutub, Muhammad. Islam The Misunderstood Religion, Terj. Fungky Kusnaedi Timur, Islam Agama Pembebasen, Jakarta Timur: Pustka al-Kautsar, 1997.

Ridjal, Fauzi. Dinamika Gerakan Perempuan Di Indonesia. Jakarta: Amzah, 2002.

Subhan, Soeleiman Fadeli Mohammad. Antologi NU, Sejarah-IstilahAmaliah-Uswah. Jakarta: Pustaka Ma'arif NU, 2007.

Suprayogo, Imam. Kyai dan Politik: Membaca Citra politik Kyai. Malang: UIN Malang Press, 2007.

Undang-Undang PEMILU, Yogykarta: Universitas Atma Jaya. 2008 